\title{
SSX4B wt Allele
}

National Cancer Institute

\section{Source}

National Cancer Institute. SSX4B wt Allele. NCI Thesaurus. Code C97817.

Human SSX4B wild-type allele is located in the vicinity of Xp11.23 and is approximately 10 $\mathrm{kb}$ in length. This allele, which encodes protein SSX4, may be involved in transcriptional regulation. 